\title{
MIR122 wt Allele
}

National Cancer Institute

\section{Source}

National Cancer Institute. MIR122 wt Allele. NCI Thesaurus. Code C82057.

The human MIR122 wild-type allele is located in the vicinity of 18q21.31 and is approximately 84 bases in length. This allele, which encodes MIR122 pre-miRNA, plays a role in the regulation of gene expression. Alteration in the expression of this gene is associated with the development of hepatocellular carcinoma. 